\title{
Meniti Jejak Perbankan Syariah dari Klasik hingga Kontemporer
}

\author{
Muhammad Syarif Hidayatullah \\ Program Doktor (S3) Ilmu Syariah Pascasarjana UIN Antasari Banjarmasin \\ Email:syarif.mubammad849@gmail.com
}

\begin{abstract}
:
The sophistication of technology and the demands of different times are important factors that have an influence on interactional activities in humans as social beings, including in the economic order. The development of the times has implications for economic activities and financial products that are utilized, in response to these developments present in the Islamic economic system that has been so developed today in the midst of the people's economy, namely Islamic banking. This study aims to describe the historical flow of Islamic banking. This research is a qualitative research with a type of literature research that uses a historical approach through descriptive analysis. Functionally viewed, actually islamic banking activities consisting of funding, financing and financial service activities have been carried out from the past on a classic basis and are individualized, then tracing up to now has become a modern and institutional basis that has relevance to the modernization and advancement of information technology. In addition, the development of Islamic banks today is inseparable from the role and struggle of Muslims who care about the application of Islamic economics.

KKecanggihan teknologi dan tuntutan zaman yang berbeda menjadi faktor penting yang membawa pengaruh terhadap aktivitas interaksional pada manusia sebagai makhluk sosial termasuk dalam tatanan perekonomian. Berkembangnya zaman ikut memberikan implikasi pada aktivitas ekonomi dan produk keuangan yang dimanfaatkan, sebagai respon dari perkembangan itu hadirlah dalam sistem ekonomi syariah yang telah begitu berkembang saat ini di tengah ekonomi masyarakat yakni perbankan syariah. Penelitian ini betujuan untuk mendeskripsikan alur historis perbankan syariah. Penelitian ini adalah penelitian kualitatif dengan jenis penelitian literatur yang menggunakan pendekatan historis melalui analisis deskriptif. Dipandang secara fungsional maka sebenarnya aktivitas perbankan syariah yang terdiri dari aktivitas penghimpunan dana, pembiayaan dan jasa keuangan telah dilaksanakan sejak dulu dengan basis klasik dan bersifat individual lalu meniti jejaknya hingga sekarang telah menjadi basis modern dan bersifat institusional yang memiliki relevansi dengan modernisasi dan kemajuan teknologi informasi. Selain itu pula berkembangnya bank syariah saat ini tidak lepas dari peran dan perjuangan umat Islam yang peduli terhadap penerapan ekonomi syariah.]
\end{abstract}

Kata Kunci: Perbankan Syariah, Sejarah, Klasik, Kontemporer 


\section{PENDAHULUAN}

Islam adalah agama rahmatan lil 'alamin (rahmat bagi seluruh alam). Islam tidak hanya mengatur pada perihal hukum ibadah, tetapi juga pada perihal hukum muamalah yang menjadikan adanya keseimbangan habluminallah wa habluminannas (hubungan manusia dengan Allah dan hubungan manusia dengan manusia). Interaksi antara satu pihak dengan pihak lainnya dalam kegiatan bermuamalah lekat hubungannya dengan korelasi pada ekonomi yang masuk pada konteks fiqih muamalah. Melalui kajian fiqih yang peka terhadap realitas yang sedang berjalan, tidak hanya memperkaya khazanah Islam, namun juga mampu mengetengahkan solusi hukum yang sesuai dengan tuntutan zaman. Fiqih atau hukum fiqih yang sesungguhnya adalah yang realistis, dalam arti berangkat dari realitas dan tidak mengabaikannya, serta terbangun atas dasar realitas dan tidak berangkat dari ruang hampa. ${ }^{1}$

Ekonomi dalam islam adalah dunia bisnis atau investasi. Hal ini bisa dicermati mulai dari tanda-tanda eksplisit untuk melakukan investasi (ajakan dalam Al-Quran dan Sunnah) hingga tanda-tanda implisit untuk menciptakan sistem yang mendukung iklim investasi (adanya sistem zakat sebagai alat disinsentif atas penumpukan harta, laranga riba untuk untuk mendukung optimalisasi investasi, serta larangan maysir atau judi dan spekulasi untuk mendorong produktivitas atas semua investasi). ${ }^{2}$

Eksistensi bisnis dan pengelolaan keuangan berbasis syariah pada penerapan sistem ekonomi islam salah satu pengaplikasiannya adalah adanya perbankan syariah. Bank syariah menjadi salah satu lembaga keuangan syariah yang begitu berkembang dan populer saat ini. Telah banyak berdiri dan beroperasi bank syariah dengan berbagai nama di banyak negara di dunia, tidak hanya di Timur Tengah atau negara mayoritas Muslim, bahkan telah merambah ke Benua Eropa. Di Indonesia pula, bank syariah telah menjadi bagian dari perekonomian masyarakat dengan hadirnya bank syariah yang tersebar di berbagai daerah di Indonesia.

\section{METODE PENELITIAN}

Metode penelitian yang digunakan adalah penelitian kualitatif dengan jenis penelitian kepustakaan (library research). Penelitian ini mengusung pendekatan historis (historical approach) melalui analisis deskriptif.

\section{HASIL DAN PEMBAHASAN Istilah "Bank"}

Istilah "bank" berasal dari bahasa Italia banco yang berarti "kepingan papan tempat buku", sejenis "meja". ${ }^{3}$ Istilah "bank" mulai populer ketika aktivitas bank modern mulai diperkenalkan di Italia yaitu di kota Florence, Venice, dan Genoa. Dari interpretasi sejarah bahwasanya penamaan ini disebabkan karena pekerjanya pada zaman dulu melakukan transaksi penukaran uang (money changer) di tempat umum dengan duduk di atas meja. Berawal dari meja tempat penukaran uang, kemudian berkembang menjadi tempat menitipkan uang (money depositor) dan tempat meminjamkan uang (money lender). Modelnya terus berkembang dan dimodernisasi hingga berevolusi menjadi bank yang saat ini dikenal.

\footnotetext{
${ }^{1}$ Moh. Nur Salim, Fikih Realistis: Kajian Tentang Hubungan antara Fikih dengan Realitas Sosial pada Masa Lalu dan Masa Kini, Versi E-Book [intisari tesis], 2009, 5.

${ }^{2}$ Ascarya, Akad dan Produk Bank Syariah: Konsep dan Praktek di beberapa Negara, Versi E-book. Jakarta: Bank Indonesia, 2006, 1.

${ }^{3}$ Muhammad Muslehuddin, Sistem Perbankan dalam Islam. Jakarta: Rineka Cipta, 2004, 1. 
Menurut Zainul Arifin, kata "bank" dapat ditelusuri dari kata banque dalam bahasa Prancis dan kata banco dalam bahasa Italia, yang dapat berarti peti/lemari atau bangku. Kata peti atau lemari menyiratkan fungsi sebagai tempat menyimpan benda-benda berharga, seperti peti emas, peti berlian, peti uang, dan sebagainya. Dewasa ini peti-bank berarti portevel aktiva yang menghasilkan (portofolio of earning assets), yaitu portofolio yang memberi bank "darah kehidupan" bernama laba bersih setelah pengeluaran-pengeluaran pajak. ${ }^{4}$ Banco atau meja para pengusaha bank pada abad pertengahan akan dimusnahkan oleh khalayak ramai, jika ia gagal menjalankan fungsinya, dan dari sinilah timbulnya istilah bangkrut. ${ }^{5}$

Bank yang pertama kali berdiri adalah di Bunduqiyyah, salah satu kota di Negara Italia pada tahun $1157 \mathrm{M}$. Kemudian terus mengalami perkembangan hingga perkembangan yang pesat sekali adalah pada abad ke-16, di mana pada tahun 1587 berdirilah di Negara Italia sebuah bank bernama Banco Della Pizza Dirialto dan berdiri juga pada tahun 1609 bank Amsterdam Belanda, kemudian berdiri bank-bank lainnya di Eropa. Sekitar tahun 1898, Bank masuk ke Negara-negara Arab, di Mesir berdiri Bank Ahli Mishri dengan modal lima ratus ribu Junaih. ${ }^{6}$

\section{Perbankan Syariah secara Teoritikal Konseptual}

Bank merupakan lembaga keuangan yang menjalankan fungsi penghimpunan dana (funding product) yang menghimpun dana dari masyarakat yang kelebihan dana (surpulus) dan fungsi penyaluran dana (financing product) kepada mereka yang kekurangan dana (deficit) serta dapat pula melaksanakan jasa-jasa lain (service). Lalu Syariah secara etimologi (bahasa) adalah jalan yang lurus. Sedangkan secara terminologi (istilah) syariah dapat diartikan peraturan-peraturan yang mengatur hubungan antara manusia dengan Allah (habluminallah) dan hubungan antara manusia dengan manusia (habluminannas). Aktivitas syariah mencakup kegiatan yang mempertimbangkan halal dan haram. ${ }^{7}$

Kata syariah di dalam versi bank syariah Indonesia adalah aturan perjanjian berdasarkan yang dilakukan oleh pihak bank dan pihak lain untuk penyimpanan dana dan/atau pembiayaan kegiatan usaha dan kegiatan lainnya sesuai dengan hukum Islam. Selain itu Bank Syariah biasa disebut Islamic Banking atau Interest Free Banking, yaitu suatu sistem perbankan dalam pelaksanaan operasional tidak menggunakan sistem bunga (riba), spekulasi (maisir), dan ketidakpastian (gharar). ${ }^{8}$

Beberapa dalil pelarangan riba, maisir dan gharar:

\section{Dalil riba}

QS. Al-Baqarah/2: 275

\footnotetext{
4Zainul Arifin, Dasar-dasar Manajemen Bank Syariah. Jakarta: Azkia Publisher, 2009, 2.

${ }^{5}$ Muhammad Muslehuddin, Sistem Perbankan...,1.

${ }^{6}$ Al-Mashorif wa Buyutu Tamwil Islamiyyah karya Ghorib al-Jamaal h. 23, Al-Muamalat Al-Maliyah AlMu'ashiroh karya Muhammad Utsman Syubair h. 252-253, Ar-Riba wal Mu'amalat Al-Mashrofiyyah karya Umar Al-Mutrik h. 309. Dikutip dalam Abu Ubaidah Yusuf bin Mukhtar as-Sidawi, Ada Apa dengan Bank Konvensional, E-Book from https://ibnumajjah.wordpress.com/.

${ }^{7}$ Muhammad Syarif Hidayatullah, Perbankan Syariah: Pengenalan Fundamental dan Pengembangan Kontemporer. Banjarbaru: Dreamedia, 2017,

8Zainuddin Ali, Hukum Perbankan Syariah. Jakarta: Sinar Grafika, 2010, 1.
}

Iqtishadia: Jurnal Ekonomi dan Perbankan Syariah 


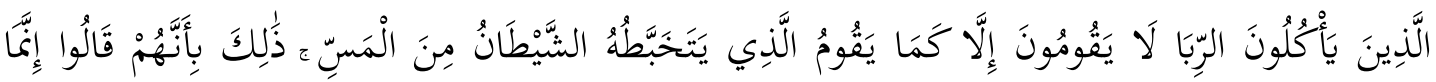

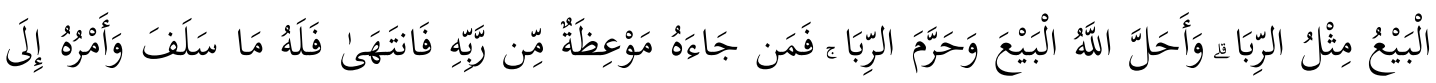

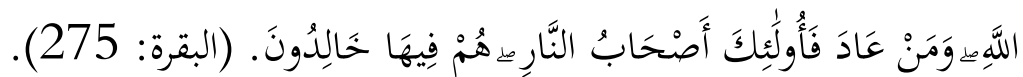

"Orang-orang yang Makan (mengambil) riba tidak dapat berdiri melainkan seperti berdirinya orang yang kemasukan syaitan lantaran (tekanan) penyakit gila. Keadaan mereka yang demikian itu, adalah disebabkan mereka berkata (berpendapat), Sesungguhnya jual beli itu sama dengan riba, Padahal Allah telah menghalalkan jual beli dan mengharamkan riba. orang-orang yang telah sampai kepadanya larangan dari Tuhannya, lalu terus berhenti (dari mengambil riba), Maka baginya apa yang telah diambilnya dahulu (sebelum datang larangan); dan urusannya (terserah) kepada Allah. orang yang kembali (mengambil riba), Maka orang itu adalah penghuni-penghuni neraka; mereka kekal di dalamnya." (QS. al-Baqarah: 275).

Dalil lainnya dalam al-Quran yakni QS. Ar-Rum/30: 39, an-Nisa/4: 161-162, dan alBaqarah: 278-279.

Hadits Nabi

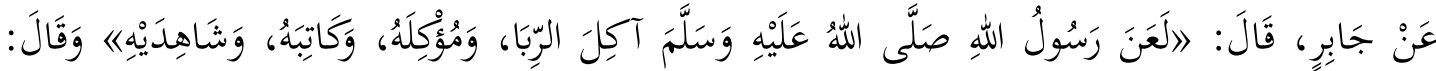

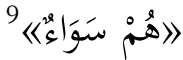

"Dari Jabir ra., ia berkata: "Rasulullah saw. melaknat orang yang memakan (mengambil) riba, memberikan, menuliskan, dan dua orang yang menyaksikannya." Ia berkata: "Mereka berstatus hukum sama." (HR. Muslim)

\section{Dalil maisir (perjudian)}

QS. Al-Maidah/5: 90-91

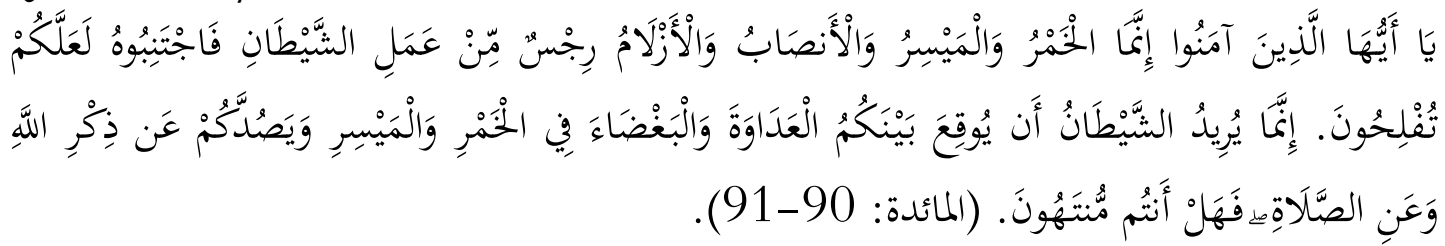

"Hai orang-orang yang beriman, Sesungguhnya (meminum) khamar, berjudi, (berkorban untuk) berhala, mengundi nasib dengan panah, adalah Termasuk perbuatan syaitan. Maka jauhilah perbuatan-perbuatan itu agar kamu mendapat keberuntungan. Sesungguhnya syaitan itu bermaksud hendak menimbulkan permusuhan dan kebencian di antara kamu lantaran (meminum) khamar dan berjudi itu, dan menghalangi kamu dari mengingat Allah dan sembahyang; Maka berhentilah kamu (dari mengerjakan pekerjaan itu)." (QS. al-Maidah: 90-91).

\footnotetext{
${ }^{9} \mathrm{Abu}$ Al-Husain Muslim Bin Al-Hajjaj, Shahih Muslim, Juz 1, Beirut: Dar Al-kutub Al-Ilmiyah, 2012, 23.
} 
Hadits Nabi

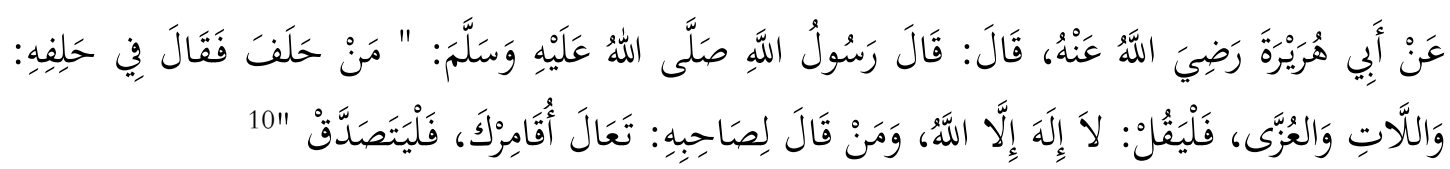

"Dari Abu Hurairah Radhiyallahuanhu, dia berkata: Rasûlullâh Shallallahu 'alaihi wa sallam bersabda: Barangsiapa bersumpah dengan mengatakan 'Demi Latta dan 'Uzza, hendaklah dia berkata, 'Lâ ilâha illa Allâh'. Dan barangsiapa berkata kepada kawannya, 'Mari aku ajak kamu berjudi', hendaklah dia bershadaqah." (HR. Al-Bukhari)

\section{Dalil gharar (ketidakjelasan)}

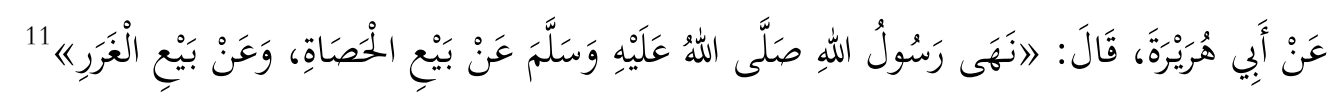

"Dari Abu Hurairah R.A ia berkata "Rasulullah Saw. melarang jual beli al-hashah dan jual beli gharar". (HR. Muslim)

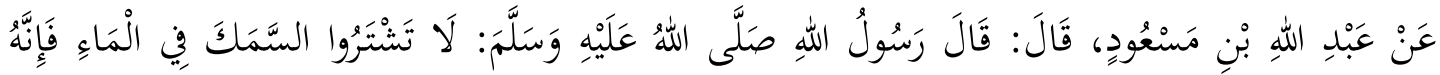

$$
\begin{aligned}
& \text { غَرَرْ . } 12
\end{aligned}
$$

"Dari Abdullah Bin Mas'ud R.A ia berkata "Rasulullah saw bersabda "Dilarang menjual ikan dalam laut, yang seperti itu gharar." (HR. Ahmad)

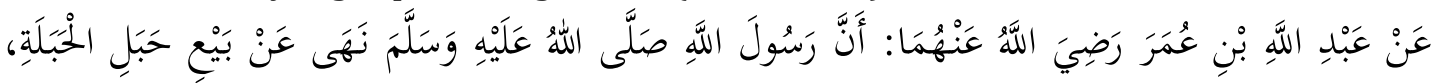

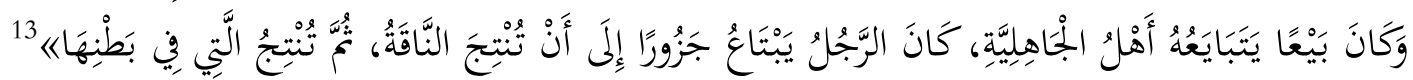

"Dari Abdullah bin Umar R.A Sesungguhnya "Rasulullah melarang jual beli habalil habalah seperti yang biasa dilakukan oleh orang-orang jahiliyyah. Biasanya seorang laki-laki membeli seekor unta hingga unta itu beranak, kemudian anaknya itu beranak pula." (HR. Al-Bukhari)

Bank Islam atau di Indonesia disebut Bank syariah merupakan lembaga keuangan yang berfungsi memperlancar mekanisme ekonomi sector riil melalui aktivitas kegiatan usaha (investasi), jual beli atau lainnya) berdasarkan prinsip syariah dengan nilai-nilai syariah bersifat makro maupun mikro. Nilai-nilai makro yang dimaksud adalah keadilan, maslahah, sistim zakat, bebas dari bunga (riba), bebas dari kegiatan spekulatif yang non produktif seperti perjudian (maysir), bebas dari hal-hal yang tidak jelas dan meragukan (gharar), bebas dari hal-hal yang rusak atau tidak sah (bathil), dan penggunaan uang sebagai alat tukar. Sedangkan nilai-nilai mikro yang dimiliki oleh pelaku Perbankan Syariah adalah sifat-sifat mulia yang dicontohkan oleh rasulullah saw., yaitu shiddiq, tabligh, amanah dan fathanah. Selain itu, dimensi keberhasilan Bank syariah meliputi keberhasilan dunia dan akhirat (long

\footnotetext{
${ }^{10} \mathrm{Abi}$ Abdillah Muhammad Bin Ismail Bin Ibrahim Bin Al-Mughirah Al-Bukhari, Shahih Al-Bukhari, Juz 3 (Beirut: Dar al-Kutub Al-Ilmiyah), 290.

11Muslim Bin Al-Hajjaj, Shahih Muslim, Juz 1, 669.

${ }^{12} \mathrm{Abu}$ Abdillah Ahmad Bin Muhammad Bin Hanbal Bin Hilal Bin Asad Asy-Syibani, Musnad Imam Ahmad Bin Hanbal, Juz 6, Beirut: Muassasah Ar- Risalah, 2001, 197.

${ }^{13} \mathrm{Al}$-Bukhari, Shahih Al-Bukhari, Juz 2, 28.
}

Iqtishadia: Jurnal Ekonomi dan Perbankan Syariah 
term oriented) yang sangat memperhatikan sumber, kebenaran proses dan kemanfaatan hasil.14

\section{Perbankan pada Masa Rasulullah saw. dan Sahabat}

Bank adalah sebuah badan usaha atau lembaga keuangan dengan fungsi mendasar dan utama yaitu menghimpun uang (simpanan), menyalurkannya (pembiayaan), dan jasa pengiriman uang (transfer). Fungsi-fungsi tersebut pada hakikatnya telah dipraktikkan sejak masa awal Islam. Jadi dalam sejarah peradaban dan perekonomian Islam, fungsi-fungsi itu memang sudah dikenal.

Rasulullah saw. dengan kredibilitasnya yang tinggi hingga beliau diberi gelar al-Amin, dipercaya oleh masyarakat Mekkah untuk menerima titipan atau simpanan harta. Sebelum beliau hijarah ke Madinah, maka beliau memerintahkan kepada Ali bin Abi Thalib untuk mengembalikan semua titipan tersebut kepada pemiliknya. Dalam hal ini penitipan yang dilakukan bersifat titipan murni tanpa dipakai (wadiah yad amanah). Seorang sahabat rasulullah saw. Zubair bin al-Awwam, memilih tidak menerima titipan harta. Beliau lebih suka menerimanya dalam bentuk pinjaman. Tindakan Zubair ini menimbulkan implikasi yang berbeda: pertama, dengan mengambil uang itu sebagai pinjaman, beliau mempunyai hak untuk memanfaatkannya; kedua, karena bentuknya pinjaman, maka ia berkewajiban mengembalikannya utuh. ${ }^{15}$

Dengan demikian, ada dua macam praktik simpanan (deposit) yang diterapkan pada masa awal Islam, yaitu wadîah yad amanah dan wadiah yad dhamanah. Munculnya variasi ini adalah karena perkembangan wacana dari pemanfaatan tipe simpanan tersebut yang dimasa rasulullah mempunyai konsep awal yaitu sebagai amanah lalu bergeser menjadi konsep pinjaman sebagaimana yang dicontohkan Zubair bin Awwam. ${ }^{16}$

Untuk fungsi kedua yaitu penyaluran uang baik konsumtif maupun produktif juga telah banyak dijalankan. Pinjaman uang (hutang) tanpa bunga sudah diajarkan rasulullah kepada umatnya dengan adanya larangan memakan harta sesama dengan cara yang bathil seperti dilakukannya transaksi ribawi yang diterangkan dalam al-Quran maupun hadits. Kemudian pemberian modal kerja berupa praktik akad kerjasama berpola bagi hasil seperti: mudhârabah, musyârakah, muzâra'ah, dan musâqah telah dipraktikkan pada masa ini.

Fungsi ketiga yaitu jasa pengiriman uang, maka dikisahkan bahwa Ibnu Abbas tercatat melakukan pengiriman uang ke Kufah. Tercatat pula Abdullah bin Zubair di Mekah juga melakukan pengiriman uang kepada adiknya Misab bin Zubair yang tinggal di Irak.

Beberapa istilah perbankan modern bahkan berasal dari khazanah ilmu fiqih, seperti istilah kredit (English: Credit; Romawi: Credo) yang diambil dari istilah qard. Credit dalam bahasa Inggris berarti meminjamkan uang; credo berarti kepercayaan; sedangkan qard dalam fiqih berarti meminjamkan uang atas dasar kepercayaan. Begitu pula istilah cek (English: check; France: Cheque) yang diambil dari istilah saq (suquq). Suquq dalam bahasa Arab berarti pasar, sedangkan cek adalah alat tukar yang biasa digunakan di pasar. ${ }^{17}$

Penggunaan cek pernah dilakukan oleh Khalifah Umar bin Khattab. Disaat mengimpor sejumlah besar barang dari Mesir ke Madinah, untuk mempercepat distribusi barang-barang tersebut kepada penduduk Madinah, maka Umar mengeluarkan cek untuk penduduk

\footnotetext{
${ }^{14}$ Ascarya, Akad dan Produk Bank Syariah, 29.

15Pusat Komunikasi Ekonomi Syariah (PKES), Perbankan Syariah. Jakarta: Pusat Komunikasi Ekonomi Syariah (pkes publishing), 2008, 8-9.

${ }^{16}$ Arifin, Dasar-dasar Manajemen Bank Syariah, 5.

${ }^{17}$ Pusat Komunikasi Ekonomi Syariah (PKES), Perbankan Syariah, 9-10.

84

Iqtishadia: Jurnal Ekonomi dan Perbankan Syariah
}

Vol. 7 No.1 Juni 2020 
Madinah yang dimaksudkan sebagai pembayaran tunjangan kepada mereka yang berhak. Hingga akhirnya dengan cek tersebut, mereka gunakan untuk mengambil gandum dari Baitul Mâl.

Meskipun tidak berbentuk lembaga, tetapi fungsi-fungsi dari bank sudah dijalankan pada masa ini yang dilaksanakan secara personal. Masyarakat di masa ini telah mengaplikasikan kegiatan seperti penitipan harta, pemberian uang (pinjaman dan investasi), dan pengiriman uang yang bersifat individu dengan satu fungsi pada satu individu.

\section{Perbankan pada Masa Bani Umayyah dan Abbasiyah}

Istilah bank memang tidak dikenal dalam kosa kata khazanah keilmuan Islam. Namun, dilihat dari segi fungsi-fungsi bank itu sendiri, hal tersebut telah lazim dipraktikkan masyarakat Islam. Dalam Islam yang dikenal adalah istilah jihbiz. Istilah jihbiz mulai dikenal pada masa Bani Umayyah dan kemudian lebih populer dan mengalami perkembangan pada masa Bani Abbasiyah.

Istilah jihbiz mulai dikenal zaman khalifah muawiyah (661-680) yang sebenarnya dipinjam dari bahasa Persia, kahbad atau kihbud. Pada masa pemerintahan Sasanid, istilah ini dipergunakan untuk orang yang ditugaskan mengumpulakn pajak tanah. ${ }^{18}$ Di zaman Bani Abbas, Jihbiz populer sebagai suatu profesi penukaran uang. Pada zaman itu mulai diperkenalkan uang jenis baru yang disebut fulus yang terbuat dari tembaga. Sebelumnya uang yang digunakan adalah dinar (terbuat dari emas) dan dirham (terbuat dari perak). Dengan munculnya fulus, timbul kecendrungan di kalangan para gubernur untuk mencetak fulusnya masing-masing sehingga beredar banyak jenis fulus dengan nilai yang berbeda-beda. Keadaan inilah yang mendorong muculnya profesi baru yaitu penukaran uang. Di zaman itu, jihbiz tidak saja melakukan penukaran uang, namun juga menerima titipan dana, meminjamkan uang, dan jasa pengiriman uang. ${ }^{19}$

Profesi jihbiz yang mengalami pergeseran fungsi di zaman Bani Abbasiyah adalah cikal bakal dari praktik money changer atau penukaran mata uang. Selain jasa penukaran uang, profesi jihbiz telah mengaplikasikan tiga fungsi mendasar dan utama bank secara sekaligus. Hal ini berarti, pada masa Abbasiyah, tiga fungsi bank dijalankan oleh satu individu dengan profesi jihbiz berbeda halnya dengan masa rasulullah saw. yang mana satu individu dengan satu fungsi.

Selain adanya profesi jihbiz, penggunaan cek telah menjadi media pembayaran praktis dengan pelopornya adalah Sayf al-Dawlah al-Hamdani. Sayf al-Dawlah al-Hamdani adalah seorang Amir di Aleppo (Spanyol) yang pernah menggunakan cek tersebut untuk membayar minuman di kedai Bani Khaqan tanpa mereka sadar kalau beliau adalah seorang Amir. Cek tersebut digunakan dalam perdagangan di Arab dan Aleppo.

\footnotetext{
${ }^{18}$ Adiwarman A. karim, Bank Islam: Analisis Fiqih dan Keuangan. Jakarta: RajaGrafindo Persada, 2008, 21. 19Pusat Komunikasi Ekonomi Syariah (PKES), Perbankan Syariah, 10.
} 
Muhammad Syarif Hidayatullah

Tabel 1

Perbandingan Perbankan Masa Rasulullah saw. \& Sahabat dengan Masa Abbasiyah

Masa Rasulullah saw. \& Sahabat

\begin{tabular}{ccc}
\hline Sifat & Individual & Individual \\
\hline Bentuk & Aktivitas di masyarakat & $\begin{array}{c}\text { Profesi yang disebut } \\
\text { jihbiz }\end{array}$ \\
\hline $\begin{array}{c}\text { Fungsi Bank oleh } \\
\text { Individu }\end{array}$ & Satu fungsi & Tiga fungsi sekaligus \\
\hline
\end{tabular}

\section{Eksistensi Bank Syariah sebagai Lembaga Keuangan Modern}

Konsep teoritis tentang suatu bank syariah telah muncul pada tahun 1940-an, namun belum dapat diwujudkan kerena selain kondisi pada waktu itu belum memungkinkan, juga belum adanya pemikiran tentang bank syariah yang meyakinkan. Pemikiran-pemikiran oleh para penulis yang mula-mula menyampaikan gagasan mengenai perbankan yang berlandaskan bagi hasil (profit sharing) tersebut ialah Anwar Qureshi (1946), Naiem Siddiqi (1948), dan Mahmud Ahmad (1952). Kemudian uraian yang lebih perinci tentang gagasan itu telah ditulis oleh Mawdudi pada tahun 1950 (1961). Tulisan-tulisan dari Muhammad Hamidullah yang ditulis pada tahun 1944, 1955, 1947, 1962 harus pula dikategorikan sebagai gagasan pendahuluan mengenai Perbankan Syariah. ${ }^{20}$

Selama dua dasawarsa berikutnya, gagasan mengenai bank bebas bunga semakin menarik perhatian. Perkembangan ini sebagian disebabkan oleh kepentingan politik di Pakistan, dan sebagian lainnya dipicu oleh kemunculan para ekonom muslim muda. Selain itu, keterlibatan berbagai lembaga dan pemerintahan turut membidani lahirnya bank-bank bebas bunga yang pertama. ${ }^{21}$

Sebenarnya upaya untuk mendirikan lembaga keuangan yang mengaplikasikan sistem syariah yaitu bagi hasil (profit and loss sharing) sebagai sistem inti bisnisnya telah dicoba pada pertengahan 1940-an di Malaysia dan di tahun 1950-an juga dicoba di Pakistan melalui pengelolaan dana jamaah haji secara nonkonvensional. Akan tetapi, ternyata kedua upaya tersebut belumlah berhasil. Kemudian pada tahun 1963, didirikanlah Lembaga Tabung Haji (Pilgrims Management Fund and Board) oleh pemerintah Malaysia yang menjalankan sistem profit and loss sharing dalam operasionalnya, namun Lembaga Tabung Haji bukanlah bank.

Pada tahun 1963 pula, akhirnya berdirilah Bank Islam yaitu Mit Ghamr Lokal Saving Bank (Bank Simpanan Lokal Mit Ghamr) atau bank yang beroperasi sebagai rural social bank $^{22}$ yang secara sederhana dapat disebut Mit Ghamr Bank. Bank ini berdiri di tepian

\footnotetext{
${ }^{20}$ Sutan Remi Sjahdeini, Perbankan Syariah: Produk-produk dan Aspek-aspek Hukumnya. Jakarta: Kencana, 2014, 49-50.

${ }^{21}$ Merwin K. Lewis \& Latifa M. Algaoud, Perbankan Syariah, terj. Burhan Subrata, Jakarta: Serambi Ilmu Semesta, 2007, 210.

${ }^{22}$ Seperti lembaga keuangan unit desa. 
sungai Nil Desa Mit Ghamr wilayah Mesir. Pendirian Mit Ghamr Bank diprakarsai oleh seorang ekonom Muslim bernama Dr. Ahmad el-Najjar dengan menerima bantuan Raja Faisal dari Arab Saudi dari segi permodalan. Dalam pendiriannya bank ini tidak secara terangterangan beridentitaskan Islam, melainkan secara tersamar dikarenakan adanya kekhawatiran terhadap pandangan rezim politik waktu itu yang mungkin akan memandangnya sebagai gerakan fundamentalis.

Mit Ghamr Bank mencoba menggabungkan gagasan bank tabungan Jerman dengan dasar-dasar perbankan untuk kawasan pedesaan yang operasionalnya berlandaskan pada tuntunan syariah Islam. ${ }^{23}$ Dan dalam hal ini Mit Ghamr Bank berhasil memadukannya dengan menerjemahkan perpaduan tersebut dalam produk-produk yang sesuai untuk daerah pedesaan yang sebagian besar orientasinya adalah industri pertanian. Maka dari itu, Mit Ghamr Bank dapat dianggap sebagai tonggak sejarah pendirian Bank Islam modern pertama dan merupakan titik balik perkembangan perbankan syariah di dunia. Mit Ghamr Bank bergerak dalam penghimpunan modal dari masyarakat, memberikan modal kepada masyarakat yang berpenghasilan rendah, tidak membebankan bunga baik dalam pinjaman maupun tabungan dan melakukan investasi secara langsung ataupun bentuk kemitraan. Mit Ghamr Bank mmenawarkan lima jenis jasa perbankan yang didasarkan atas prinsip syariah. jasa-jasa perbankan tersebut adalah rekening simpanan (deposit accounts), rekening pembiayaan (financial accounts), penyertaan modal (equity participation), investasi langsung (direct investment), dan jasa-jasa sosial (social services).

Keberhasilan Mit Ghamr Bank mendapat pujian dari penghargaan the Ford Fondation. Dalam laporannya yang dikeluarkan pada bulan Juni 1967, the Ford Fondation memuji keberhasilan bank tersebut dalam memperoleh dukungan dari para petani dan penduduk. Dilihat dari peningkatan pertumbuhan jumlah nasabah penyimpan dan dana simpanan sangat cepat selama empat tahun semnjak bank tersebut beroperasi. Total jumlah penyimpan meningkat $73 \%$ untuk tahun 1964/1965. Kemudian meningkat $400 \%$ pada tahun 1965/1966 dan 60 \% pada tahun 1966/1967. Jumlah dana simpanan meningkat $367 \%$ pada tahun 1964/1965, $360 \%$ pada tahun 1965/1966, dan $108 \%$ pada tahun 1966/1997.24

Pada tahun1967, disebabkan persoalan politik yang terjadi di Mesir, National Bank of Egypt dan Egypt Central Bank mengambilalih Mit Ghamr Lokal Saving Bank. Setelah pengambilalihan, sistem bank yang awalnya syariah berubah menjadi non syariah dengan diterapkannya bunga pada produk-produknya. Para nasabahpun turun drastis dengan terjadinya perubahan sistem ini. Pada tahun 1972, akhirnya sistem syariah kembali digalangkan dibawah pemerintahan Anwar al-Sadat dengan didirikannya Nasser Social Bank oleh pemerintah, kemudian mendeklarasikan diri sebagai Bank yang bebas bunga walaupun dalam akta pendiriannya tidak disebutkan kepada agama dan syariat Islam. Dibandingkan dengan pendahulunya Mit Ghamr Bank, Nasser Social Bank menawarkan jasa perbankan dengan skala yang lebih luas seperti adanya jasa penukaran valuta asing (foreign exchange services) dan Nasser Social Bank pun mendapat dukungan penuh dari pemerintah.

23Muhammad Syafi'i Antonio et al, Bank Syariah: Analisis Kekuatan, Kelemahan, Peluang, dan Ancaman. Yogyakarta: Ekonisia, 2008, 139.

${ }^{24}$ Haron Sudin, Wan Asmi, \& Wan Nursofiza, Islamic Finance and Banking System: Philosophies, Principles \& Practices. McGraw Hill Education, 2009, 64, dikutip dalam Sutan Remi Sjahdeini, Perbankan Syariah..., 65-66.

Iqtishadia: Jurnal Ekonomi dan Perbankan Syariah 
Tabel 2

Perbandingan Jihbiz dengan Bank

\begin{tabular}{|c|c|c|}
\hline & Jihbiz & Bank \\
\hline Sifat & Individual & Institusional \\
\hline Bentuk & Profesi & Lembaga Komersial \\
\hline Fungsi yang Dijalankan: & Tiga fungsi sekaligus & Tiga fungsi sekaligus \\
\hline $\begin{array}{l}\text { *enghimpunan } \\
\text { dana }\end{array}$ & & \\
\hline * Penyaluran dana & & \\
\hline $\begin{array}{l}\text { *asa pengiriman } \\
\text { uang }\end{array}$ & & \\
\hline
\end{tabular}

\section{Internasionalisasi Perbankan Syariah}

Latar belakang kemunculan Organisasi Konferensi Islam (OKI) yang beranggotakan pemerintah berbagai negara berpenduduk Muslim pada awalnya dikaitkan dengan upaya pembebasan rakyat Palestina dari penjajahan Israel. Selanjutnya kiprah dari OKI tidaklah sebatas itu, dengan segenap kelembagaan dan potensi yang dimiliknya OKI memainkan peran yang lebih luas, yakni mencakup berbagai persoalan yang dihadapi dunia Islam dibidang politik, ekonomi, sosial, pendidikan, kebudayaan, dan sebagainya.

Persoalan perbankan yang merupakan turunan dari ekonomi adalah permasalahan kompleks yang dihadapi oleh umat Islam diseluruh dunia. Dalam kehidupan yang sudah modern, maka transaksi perbankan menjadi bagian penting dalam perekonomian masyarakat yang merupakan bagian dari kegiatan bermuamalah. Sistem non syariah yang diterapkan pada lembaga perbankan membuat umat muslim menghadapi dilema atas keadaan yang dihadapi. Disatu sisi mereka memerlukan transaksi tersebut, akan tetapi disisi lain terdapat unsur terlarang yaitu riba dengan bentuk bunga yang diaplikasikan dalam produk yang ditawarkan. Maka dari itu, umat muslim sangat mendambakan hadirnya bank yang bebas dari bunga.

Keberhasilan Dr. Ahmad el-Najjar mendirikan Mit Ghamr Bank menjadi tindakan inspiratif bagi banyak pihak. Eksperimen (pilot project) dari Dr. Ahmad el-Najjar ini sukses dalam manajemen bank berbasis syariah. Sistem yang dijalankan tidaklah berbasis bunga (interest), melainkan bagi hasil (profit and loss sharing). Selanjutnya pada tahun 1965, proyek Bank Syariah dilakukan di Pakistan dengan berdirinya Bank Koperasi. Gerakan Bank Syariah mulai hidup dan gencar pada pertengahan tahun 1970-an.

Catchment area (wilayah penampungan) paling nyata untuk perbankan Islam adalah komunitas muslim internasional. ${ }^{25}$ Gagasan berdirinya Bank Syariah di tingkat Internasional muncul dalam konferensi negara-negara Islam sedunia yang diselenggarakan di Kuala

${ }^{25}$ Lewis \& Latifa M. Algaoud, Perbankan Syariah, 384. 
Lumpur, Malaysia pada tanggal 21-27 April 1969. Konferensi yang diikuti 18 negara peserta itu memutuskan beberapa hal sebagai berikut: 26

1. Tiap keuntungan haruslah tunduk kepada hukum untung dan rugi. Jika demikian, maka hal itu termasuk riba, dan riba itu sedikit atau banyak hukumnya haram.

2. Diusulkan supaya dibentuk suatu Bank Syariah yang bersih dari sistem riba dalam waktu secepat mungkin.

3. Sementara Bank Syariah belum beridir, bank-bank yang menerapkan bunga masih diperbolehkan untuk beroperasi, hanya apabila memang benar-benar dalam keadaan darurat.

Pada Sidang Menteri Luar Negeri Negara-Negara Organisasi Konferensi Islam (OKI) di Karachi Pakistan bulan Desember 1970 dengan Agenda pertemuan adalah "Economic, Cultural, and Social Cooperation among Participating States", delegasi Mesir mengajukan sebuah proposal untuk mendirikan Bank Syariah yang mendapat respon positif dari 18 negara muslim pada waktu itu. Lebih spesifiknya tentang proposal yang diajukan adalah berupa studi tentang pendirian Bank Islam Internasional untuk Perdagangan dan Pembangunan (International Islamic Bank for Trade and Development) dan proposal pendirian Federasi Bank Islam (Federation of Islamic Banks). Selain itu pula, terdapat usulan tentang pembentukan badan-badan khusus yang disebut Badan Investasi dan Pembangunan Negara-negara Islam (Investment and Development Body of Islamic Countries), serta pembentukan perwakilan-perwakilan khusus yaitu Asosiasi Bank-bank Islam (Association of Islamic Banks) sebagai badan konsultatif masalah-masalah ekonomi dan Perbankan Islam.

Pada Sidang Menteri Luar Negeri OKI di Benghazi, Libya bulan Maret 1973 dengan forum yang sama, pembahasan tentang proposal tersebut kembali diagendakan. Sidang akhirnya memutuskan bahwa OKI harus memiliki badan khusus yang menangani masalah ekonomi dan keuangan. Kemudian pada bulan Juli di tahun yang sama, komite ahli pendirian bank Islam bertemu di Jeddah, Arab Saudi. Setelah itu pada tahun 1974, berdasarkan rekomendasi pada sidang sebelumnya, maka dibahaslah anggaran dasar dan anggaran rumah tangga (ADART) Bank Islam tersebut. Puncaknya adalah pada Oktober 1975, Islamic Depelopment Bank (IDB) secara resmi didirikan dengan kesepakatan/persetujuan (agreement) yang ditandatangani oleh 22 negara dengan modal awal 2 miliar dinar.

Proses yang cukup panjang dalam pendirian Islamic Development Bank (IDB) atau Bank Pembangunan Islam tidaklah sia-sia. Karena setelah itu menjadi pemicu munculnya lembagalembaga keuangan Islam di Mesir, Sudan, negara-negara Teluk, Pakistan, Iran, Malaysia, Bangladesh dan Turki. Disebutkan oleh Muhammad Syafi'i Antonio, bahwa secara garis besar, lembaga-lembaga keuangan yang berkembang tersebut dapat dimasukkan ke dalam dua kategori. Pertama, Bank Islam Komersial (Islamic Commercial Bank). Kedua, lembaga investasi dalam bentuk International Holding Companies. ${ }^{27}$

Sejumlah bank syariah muncul dibeberapa negara pada kurun 1970-an. Di Timur Tengah antara lain berdiri Dubai Islamic Bank (1975), Faisal Islamic Bank of Sudan (1977), Faisal Islamic Bank of Egypt (1977) serta Bahrain Islamic Bank (1979). Dia Asia, Phillipine Amanah Bank didirikan tahun 1973 di Filipina dan di Malaysia tahun 1983 berdiri Muslim Pilgrims Savings Corporation atau lembaga tabung haji yang bertujuan membantu mereka yang ingin menabung untuk menunaikan ibadah haji, namun lembaga keuangan syariah ini bukanlah bank, sedangkan bank syariah pertamanya adalah Bank islam Malaysia Berhad (BIMB) yang berdiri pada tahun 1983. Penyebaran bank syariah bahkan juga sampai ke

${ }^{26}$ Sjahdeini., Perbankan Syariah, 51.

27 Antonio, Bank Syariah, 21.

Iqtishadia: Jurnal Ekonomi dan Perbankan Syariah

Vol. 7 No. 1 Juni 2020 
negara barat, The Islamic Bank International of Denmark tercatat sebagai bank syariah pertama yang beroperasi berdasarkan prinsip syariah yang mulai beroperasi di tahun 1983 di Denmark.

\section{Lembaga Afiliasi Bank Syariah Internasional}

Islamic Development Bank (IDB) sebagai Bank Syariah berskala internasional memiliki afiliasi dengan berbagai lembaga. Lembaga yang terafiliasi dengan IDB yaitu:28

1. Islamic Corporation for Insurance of Investments and Export Credits (ICIEC)

ICIEC didirikan pada tahun 1415H (1994) dengan tujuan untuk memperbesar cakupan transaksi perdagangan dan arus investasi di antara negara-negara anggota Organisasi Konferensi Islam (OKI).

2. Islamic Research and Training Institute (IRTI)

IRTI didirikan pada tahun $1981(1401 \mathrm{H})$ untuk membantu bank dalam menjalankan fungsinya di bidang riset dan pelatihan. IRTI juga bertujuan untuk melakukan penelitian dan menyediakan pelatihan dan layanan informasi di negara-negara anggota dan masyarakat muslim di negara-negara non-anggota, membantu dalam bidang ekonomi, baik dalam hal keuangan maupun kegiatan perbankannya agar sesuai dengan prinsip syariah serta mampu mempercepat pembangunan ekonomi dan meningkatkan kerjasama di antara negara anggota maupun non-anggota.

3. Islamic Corporation for the Development of the Private Sector (ICD)

ICD ini didirikan pada bulan November 1999 (Rajab 1420H) yang memiliki tujuan untuk mengidentifikasi peluang investasi di sektor swasta di negara-negara anggota sehingga mempercepat pertumbuhan ekonomi, untuk menyediakan berbagai produk dan jasa keuangan berbasis syariah yang kompatibel serta memperluas akses ke pasar modal Islam oleh perusahaan swasta di negara-negara anggota.

4. International Islamic Trade Finance Corporation (ITFC)

Para Dewan Gubernur IDB menyetujui pembentukan International Islamic Trade Finance Corporation (ITFC) dalam pertemuan yang berlangsung pada bulan Juni 2005 (Jumad Awwal 1426H). Tujuannya adalah untuk mempromosikan perdagangan di negaranegara anggota Islamic Development Bank dengan memberikan pembiayaan perdagangan dan terlibat dalam kegiatan-kegiatan yang memfasilitasi perdagangan intra dan perdagangan internasional.

5. World Waqf Foundation (WWF)

WWF didirikan oleh IDB pada tahun 2001 (1422H) sebagai tanggapan terhadap kebutuhan untuk menciptakan entitas global untuk wakaf, bekerjasama dengan organisasiorganisasi wakaf milik pemerintah, LSM dan kaum dermawan dari sektor swasta.

\section{Kehadiran Bank Syariah di Indonesia}

Umat Islam di Indonesia telah lama mendambakan adanya bank yang beroperasi sesuai syariat Islam. K.H. Mas Mansur sebagai ketua pengurus besar Muhammadiyah periode 19371944 mengeluarkan pendapatnya mengenai penggunaan jasa bank konvensional yang terpaksa dilakukan karena umat Islam belum mempunyai lembaga keuangan sendiri yang

${ }^{28}$ Hidayatullah, Perbankan Syariah, 196-198.

$90 \quad$ Iqtishadia: Jurnal Ekonomi dan Perbankan Syariah

Vol. 7 No.1 Juni 2020 
bebas riba. ${ }^{29}$ Masyarakat muslim sangat mendambakan keberadaan bank sebagai lembaga perekonomian umat yang menjalankan operasionalnya berdasar pada nilai-nilai Islam

Pada periode tahun 1970, ide pendirian bank syariah di Indonesia gencar digagas. Dimana pembicaraan Bank Syariah muncul pada seminar hubungan Indonesia-Timur Tengah pada tahun 1974 dan 1976 dalam seminar yang diadakan oleh Lembaga Studi Ilmu-Ilmu kemasyarakatan dan Yayasan Bhineka Tunggal Ika. Perkembangan pemikiran tentang perlunya umat Islam di Indonesia memiliki Bank Islam dimulai sejak itu, seiring munculnya kesadaran kaum Intelektual dan cendikiawan muslim dalam memberdayakan ekonomi masyarakat. Selanjutnya melalui diskusi bertemakan Bank Islam sebagai Pilar Ekonomi Islam di awal tahun 1980-an merupakan pergerakan aktif dalam upaya menggagas adanya Bank Islam di Indonesia. Tokoh-tokoh yang terlibat dalam diskusi tersebut antara lain: Karnaen A. Perwataatmadja, M. Dawam Rahardjo, A. M. Saefuddin, dan M. Amien Azis.

Ada dua kebijakan penting yang mulai membuka celah untuk perbankan syariah Memasuki tahun 1980-an, yaitu deregulasi sektor perbankan melalui Paket Kebijakan 1 Juni 1983 (Pakjun 83) tentang penghapusan pagu kredit lalu dikeluarkannya Paket Kebijakan 27 Oktober 1988 (Pakto 88). Dua paket kebijakan ini mempengaruhi bagaimana perkembangan perbankan di Indonesia. Pakjun 83 berkenaan tentang penghapusan pagu kredit yang menyebutkan bank bebas dalam menentukan suku bunga kredit, suku bunga tabungan dan deposito. Ini menjadi landasan yang menyatakan bahwa bank diperbolehkan untuk memberikan kredit dengan bunga $0 \%$, yang artinya terdapat peluang untuk adanya bank bebas bunga.

Akan tetapi, walaupun peluang itu sudah terlihat, namun dalam realitanya banyak kendala yang dihadapi, seperti: (a) Operasi bank syariah yang menerapkan sistem bagi hasil belum ada diatur dalam perundang-undangan. (b) Konsep bank syariah dari segi politis juga dapat dianggap berkonotasi ideologis yang baru dikaitkan dengan negara Islam..$^{30}$ Selain itu juga belum memungkinkan pendirian bank baru dengan adanya kebijakan pembatasan bank asing yang ingin membuka kantor cabang di Indonesia dan ini mencegah pendirian bank baru dari negara-negara Timur Tengah. Dan masih belum memungkinkan pula pendirian bank baru oleh orang Indonesia sendiri.

Dengan begitu, dikarenakan belum dimungkinkannya pendirian bank baru, maka digunakan badan hukum koperasi sebagai bentuk hukumnya. Pemilihan badan hukum koperasi sebagai wadah penerapan sistem Perbankan Syariah telah dimulai oleh Koperasi Jasa Keahlian Teknosa di Bandung sejak awal tahun 80-an. Kemudian di Jakarta didirikan Baitut Tamwil kedua dengan nama Koperasi Simpan Pinjam Ridho Gusti yang didirikan tanggal 25 September 1988. ${ }^{31}$ Setelah itu akhrinya dikeluarkanlah Paket Kebijakan 27 Oktober 1988 (Pakto 88) tentang izin pendirian usaha bank baru.

Akhirnya dikeluarkanlah Pakto 88 tentang izin pendirian usaha bank baru (liberalisasi industri perbankan) yang memberikan kemudahan bagi pendirian bank-bank baru selain bank-bank yang sudah ada, sehingga industri perbankan pada waktu itu mengalami pertumbuhan yang sangat pesat. Pada saat itulah para ulama Indonesia berusaha untuk mendirikan bank bebas bunga, tetapi tidak ada satupun perangkat hukum untuk dijadikan

\footnotetext{
${ }^{29}$ Gemala Dewi, Aspek-aspek Hukum dalam Perbankan dan Perasuransian Syariah di Indonesia. Jakarta: Kencana, 2007, 57-58.

${ }^{30}$ M. Ma'ruf Abdullah, Hukum Perbankan dan Perkembangan Bank Syariah di Indonesia. Banjarmasin: Antasari Press, 2006, 17.

31Wirdyaningsih et al, Bank dan Asuransi Islam di Indonesia. Jakarta: Kencana, 2005, 50.
} 
dasar pendiriannya, kecuali bahwa bank dapat menetapkan bunga sebesar 0\%. Sehingga gagasan masih gagal dilakukan oleh para ulama di Indonesia.

Melalui penjelasan dari pemerintah dalam Rapat Komisi VII DPR RI tanggal 5 Juli 1990 yang menyatakan bahwa tidak ada halangan untuk mendirikan atau mengoperasikan bank yang sesuai dengan prinsip-prinsip syariah Islam selama memenuhi kriteria kesehatan bank yang telah ditetapkan oleh Bank Indonesia, maka menjadi dukungan tambahan dari keinginan kuat umat Islam di Indonesia terhadap Bank Islam. ${ }^{32}$

Prakarsa lebih khusus untuk mendirikan bank syariah di Indonesia baru dilakukan secara mendalam pada tahun 1990. MUI melaksanakan Lokakarya Bunga Bank dan Perbankan di Cisarua, Bogor, Jawa barat pada tanggal 18-20 Agustus 1990. Ide pendirian Bank Islam kemudian lebih dipertegas lagi dalam Musyawarah Nasional (MUNAS) ke IV MUI di Hotel Sahid Jaya Jakarta tanggal 22-25 Agustus 1990 yang mengamanahkan kepada Bapak K.H. Hasan Bahri yang terpilih kembali sebagai Ketua Umum MUI, untuk merealisasikan pendirian Bank syariah tersebut. Berdasarkan Munas IV MUI terbentuklah kelompok kerja (Pokja) untuk mendirikan Bank syariah di Indonesia. Tim Pokja bertugas melakukan pendekatan dan konsultasi dengan semua pihak terkait.

Tim Pokja membentuk tim kecil "Penyiapan Buku Panduan Bank Tanpa Bunga" yang diketuai oleh Dr. Ir. M. Amin Aziz dengan anggota M. Syahrul Rali Siregar, A. Malik, Zainulbahar Noor, SE. Kemudian tim kecil ini diperkuat dengan Ir. Abdul Aziz, Kuntoadji, Drs. Amir R. Batubara, Drs. Karnaen Perwataadmadja, MPA, Drs. Faudi Morad, Chalid Hsb., BA, Jimly Asshiddiqie, MA dan Abdul Mughni, MBA. ${ }^{33}$ Hal paling utama dilakukan oleh Tim MUI ini di samping melakukan pendekatan-pendekatan dan konsultasi dengan pihak-pihak terkait adalah menyelenggarakan pelatihan calon staf melalui Management Development Program (MDP) di Lembaga Pendidikan Perbankan Indonesia (LPPI), Jakarta yang dibuka pada tanggal 29 Maret 1991 oleh Menteri Keuangan, dan meyakinkan beberapa pengusaha muslim untuk jadi pemegang saham pendiri. Untuk membantu kelancaran tugas-tugas MUI ini dibentuklah Tim Hukum Ikatan Cendekiawan Muslim Indonesia (ICMI) yang di bawah Ketua Drs. Karnaen Perwaatmadja, MPA. Tim ini bertugas untuk mempersiapkan segala sesuatu yang menyangkut aspek hukum Bank Islam.

Ketika pendirian bank syariah oleh MUI bersama timnya masih dalam proses, dimasa proses tersebut telah berhasil didirikan Bank Perkreditan Rakyat (BPR) bebas bunga di Bandung yakni BPR Dana Mardhatillah dan BPR Berkah Amal Sejahtera pada tanggal 19 Agustus 1991 dan BPR Amanah Rabbaniah pada tanggal 24 Oktober 1991. Upaya dari Tim perbankan MUI dalam merealisasikan gagasan berdirinya Bank syariah pada akhirnya menemui kesuksesan dengan berhasil mendirikan Bank Muamalat Indonesia pada tanggal 1 November 1991 dengan penandatanganan akte pendirian yang disertai terkumpulnya komitmen pembelian saham sebesar Rp 84 Miliar. Pada acara silaturahmi pendirian Bank syariah di Istana Bogor, diperoleh tambahan komitmen dari masyarakat Jawa Barat yang turut menenanam modal senilai Rp 106 miliar. Dengan angka modal awal ini Bank Muamalat mulai beroperasi pada tanggal 1 Mei 1992.

\section{Lembaga Keuangan Syariah Selain Bank Syariah}

Sistem ekonomi Islam telah diterapkan dalam kelembagaan modern. Lembaga-lembaga tersebut menjadi bagian penting dimasyarakat yang membantu dalam transaksi keuangan dengan berbagai bentuk dan produk. Lembaga-lembaga tersebut selain Bank Syariah yakni:

\footnotetext{
32Burhanuddin Susanto, Hukum Perbankan Syariah di Indonesia. Yogyakarta: UII Press, 2008, 180.

33Ibrahim Lubis, Ekonomi Islam: Suatu Pengantar II, Jakarta: Kalam Mulia, 1995, 678-679. 


\section{Baitul Mal wat Tamwil (BMT)}

Baitul Mal wat Tamwil (BMT) merupakan penggabungan dari Baitul Mal dan Baitut Tamwil . Lembaga ini menggabungkan aktivitas sosial dan komersial yang berbentuk layanan keuangan dan sektor riil serta pengelolaan zakat, infaq dan shadaqah. Dengan begitu menggabungkan dua hal yang beda sifatnya yakni transaksi mencari laba dan nirlaba. Namun dalam operasionalnya BMT tetaplah sebuah entitas yang terpisah. ${ }^{34}$

\section{Asuransi Syariah}

Asuransi Syariah adalah suatu pengaturan pengelolaan resiko yang memenuhi ketentuan syariah, tolong-menolong secara mutual yang melibatkan peserta dan operator. 35 Perusahaan asuransi syariah adalah lembaga yang kegiatan usahanya saling melindungi dan tolong-menolong diantara sejumlah orang/pihak melalui investasi dalam bentuk asset/tabarru yang memberikan pola pengembalian untuk menghadapi resiko tertentu melalui akad yang sesuai syariah. ${ }^{36}$

\section{Pegadaian Syariah}

Perusahaan pegadaian merupakan lembaga keuangan yang menyediakan fasilitas pinjaman dengan jaminan tertentu. ${ }^{37}$ Pandangan para ahli dalam Ade Sofyan Mulazid memaparkan bahwa keberadaan pegadaian dengan tujuan melaksanakan pembangunan ekonomi nasional, membantu masyarakat yang memerlukan uang agar tidak bertransaksi dengan rentenir dan upaya preventif dalam transaksi pinjaman tidak wajar lainnya. ${ }^{38}$ Dengan begitu pegadaian syariah adalah lembaga keuangan yang melakukan usaha dibidang gadai maupun fidusia dengan operasional berbasis islam melalui penerapan akad ar-rahn dan nilainilai ekonomi Islam lainnya.

\section{Perusahaan Pembiayaan Syariah}

Perusahaan Pembiayaan Syariah adalah Perusahaan Pembiayaan yang seluruh kegiatan usahanya melakukan pembiayaan syariah. ${ }^{39}$ Setiap perusahaan pembiayaan yang melakukan kegiatan usaha berdasarkan prinsip syariah wajib menyalukan dana untuk kegiatan pembiayaan berdasarkan prinsip syaiah. Pembiayaan berdasarkan prinsip syariah yang disalurkan oleh perusahaan pembiayaan dapat merupakan komponen investasi, piutang pembiayaan, atau piutang sewa. ${ }^{40}$

\footnotetext{
${ }^{34}$ Hertanto Widodo, et. al, PAS (Pedoman Akuntansi Syariah): Panduan Praktis Operasional Baitul Mal wat Tamwil (BMT), Bandung: Mizan, 2000, 81-82.

${ }^{35}$ Muhaimin Iqbal, Asuransi Umum Syariah dalam Praktik. Jakarta: Gema Insani Press, 2005, 2.

${ }^{36}$ Shinta Dewianty, "Sistem Lembaga Keuangan Syariah", Economic: Jurnal Ekonomi dan Hukum Islam, Vol. 2, No. 1, 2012, 54.

37 Shinta Dewianty, "Sistem Lembaga Keuangan Syariah", 56

${ }^{38}$ Ade Sofyan Mulazid, Kedudukan Sistem Pegadaian Syariah dalam Sistem Hukum di Indonesia. Jakarta: Kemenag RI, 2012, 108.

${ }^{39}$ Lihat Pasal 1 Angka 3 Peraturan Otoritas Jasa Keuangan No. 10 /POJK.05/2019 tentang Penyelenggaraan Usaha Perusahaan Pembiayaan Syariah dan Unit Usaha Syariah Perusahaan Pembiayaan.

${ }^{40}$ Andri Soemitra, Bank dan Lembaga Keuangan Syariah. Jakarta: Kencana Prenada Media Group, 2012, 337.
} 


\section{Reksa Dana Syariah}

Reksa Dana Syariah merupakan perusahaan sekuritas yang khusus memfasilitasi investor untuk menginvestasikan dananya pada surat berharga yang memenuhi kriteria syariah. ${ }^{41}$ Kebijakan investasi reksa dana syariah adalah berbasis instrumen investasi dengan cara-cara pengelolaan yang halal. Halal disini berarti bahwa perusahaan yang mengeluarkan instrumen investasi tersebut tidak boleh melakukan usaha-usaha yang bertentangan dengan prinsip Islam. Tujuan utama investasi reksa dana syariah adalah untuk memenuhi kebutuhan kelompok investor yang ingin memperoleh pendapatan dari sumber dan dengan cara yang bersih, sejalan dengan prinsip syariah, dan dapat dipertanggungjawabkan secara religius. Oleh karena itu, reksa dana syariah merupakan wadah yang digunakan oleh masyarakat untuk berinvestasi dengan mengacu pada syariat Islam.

\section{Pasar Modal Syariah}

Istilah pasar biasanya digunakan istilah bursa, exchange dan market. Sementara untuk istilah modal sering digunakan istilah efek, securities dan stock. Pasar modal menurut Undang-undang No. 8 Tahun 1995 tentang Pasar Modal Pasal 1 Ayat (12) adalah kegiatan yang bersangkutan dengan penawaran umum dan perdagangan efek, Perusahaan publik yang berkaitan dengan efek yang diterbitkannya, serta lembaga dan profesi yang berkaitan dengan efek. Sedangkan yang dimaksud dengan efek pada Pasal 1 Ayat (5) adalah surat berharga, yaitu surat pengakuan utang, surat berharga komersial, saham, obligasi, tanda bukti utang, unit penyertaan kontrak investasi kolektif, kontrak berjangka atas efek, dan setiap derivatif dari efek. ${ }^{42}$ Kegiatan di pasar modal syariah berkaitan dengan perdagangan surat berharga (efek syariah) yang telah ditawarkan kepada masyarkat dalam bentuk penyertaan kepemilikan saham atau penerbitan obligasi syariah

\section{Lembaga Zakat, Infaq dan shadaqah (ZIS)}

Selain lembaga-lembaga keuangan berorientasi profit yang telah disebutkan sebelumnya, terdapat pula lembaga modern dengan sistem ekonomi Islam yang merupakan lembaga sosial yakni lembaga pengelola zakat, infaq dan shadaqah. Lembaga tersebut bergerak pada penghimpunan dan pendistribusian ZIS dari para muzakki kepada para mustahiq.

\section{PENUTUP}

Aktivitas perbankan secara Islam bukanlah sesuatu yang baru muncul pada zaman sekarang, melainkan telah ada sejak dulu. Hanya saja aktivitas perbankan saat ini telah menyesuaikan dengan budaya dan peradaban dalam alur perkembangan zamannya yang dinamis. Aktivitas perbankan syariah secara klasik masih belum didukung dengan fasilitasfasilitas yang sudah sangat berkembang pada aktivitas perbankan syariah dengan segala modernisasi dan pengaruh teknologi informasi. Selain itu pula keadaan zaman yang berubah menjadi pembeda diantara keduanya.

Perbankan syariah telah menjadi bagian penting ditengah perekonomian umat Islam. Mulai berkembangnya perbankan syariah pada saat ini memang tidak terlepas dari peran dan perjuangan para kaum muslimin yang ingin menerapkan sistem ekonomi yang islami. Dari dulu hingga sekarang perbankan syariah meniti jejaknya hingga berkembang diberbagai

\footnotetext{
${ }^{41}$ Rizal Yaya, Akuntansi Perbankan Syariah: Teori dan Praktik Kontemporer. Jakarta: Salemba Empat, 2012, 24.

${ }^{42}$ Soemitra, Bank dan Lembaga Keuangan Syariah, 109.

94

Iqtishadia: Jurnal Ekonomi dan Perbankan Syariah
}

Vol. 7 No.1 Juni 2020 
Negara termasuk Indonesia dan telah hadir pula bank syariah berskala internasional yakni Islamic Development Bank. Berbagai hal yang menjadi faktor penting atau banyak kaitannya dengan perkembangan perbankan syariah mengikuti langkah maju perbankan syariah itu sendiri. Selain bank syariah, terdapat lembaga keuangan syariah lainnya yang turut serta hadir di tengah masyarakat seperti Baitul Mal wat Tamwil (BMT), pegadaian syariah, perusahaan pembiayaan syariah, Asuransi Syariah, Pasar Modal Syariah, Reksa Dana Syariah dan Lembaga Pengelola Zakat, Infaq dan Shadaqah (ZIS).

\section{DAFTAR PUSTAKA}

Abdullah, M. Ma'ruf. Hukum Perbankan dan Perkemabngan Bank Syariah di Indonesia. Banjarmasin: Antasari Press, 2006.

Al-Bukhari, Abi Abdillah Muhammad Bin Ismail Bin Ibrahim Bin Al-Mughirah. Shahih alBukhari. Juz 3. Beirut: Dar al-Kutub al-Ilmiyah.

Al-Hajjaj, Abu al-Husain Muslim Bin. Shahih Muslim. Juz 1. Beirut: Dar al-Kutub al-Ilmiyah, 2012.

Ali, Zainuddin. Hukum Perbankan Syariah. Jakarta: Sinar Grafika, 2010.

Antonio, Muhammad Syafi'i et al. Bank Syariah: Analisis Kekuatan, Kelemahan, Peluang dan Ancaman. Yogyakarta: Ekonisia, 2008.

Arifin, Zainul. Dasar-dasar Manajemen Bank Syariah. Jakarta: Azkia Publisher, 2009.

Ascarya. Akad dan Produk Bank Syariah: Konsep dan Praktek di Beberapa Negara, Versi EBook. Jakarta: Bank Indonesia, 2006

As-Sidawi, Abu Ubaidah Yusuf bin Mukhtar Ada Apa dengan Bank Konvensional, E-Book from https://ibnumajjah.wordpress.com/.

Asy-Syibani, Abu Abdillah Ahmad Bin Muhammad Bin Hanbal Bin Hilal Bin Asad. Musnad Imam Ahmad bin Hanbal. Juz 6. Beirut: Muassasah ar-Risalah, 2001.

Dewi, Gemala. Aspek-aspek Hukum dalam Perbankan dan Perasuransian Syariah di Indonesia. Jakarta: Kencana, 2007.

Dewianty, Shinta. 2012. "Sistem Lembaga Keuangan Syariah". Economic: Jurnal Ekonomi dan Hukum Islam, Vol. 2, No. $1 \mathrm{~m}$ h. 41-70.

Hidayatullah, Muhammad Syarif. Perbankan Syariah: Pengenalan Fundamental dan Pengembangan Kontemporer. Banjarbaru: Dreaamedia, 2017.

Iqbal, Muhaimin. Asuransi Umum Syariah dalam Praktik. Jakarta: Gema Insani Press, 2005.

Karim, Adiwarman A. Bank Islam: Analisis Fiqih dan Keuangan. Jakarta: RajaGrafindo Persada, 2008.

Lewis, Merwin K. dan Latifa M. Algoud. Perbankan Syariah, terj. Burhan Subrata. Jakarta: Serambi Ilmu Semesta.

Lubis, Ibrahim. Ekonomi Islam: Suatu Pengantar II. Jakarta: Kalam Mulia, 1995.

Mulazid, Ade Sofyan. Kedudukan Sistem Pegadaian Syariah dalam Sistem Hukum di Indonesia. Jakarta: Kemenag RI, 2012.

Muslehuddin, Muhammad. Sistem Perbankan dalam Islam. JakartaL Rineka Cipta, 2004.

Peraturan Otoritas Jasa Keuangan No. 10 /POJK.05/2019 tentang Penyelenggaraan Usaha Perusahaan Pembiayaan Syariah dan Unit Usaha Syariah Perusahaan Pembiayaan.

Pusat Ekonomi Ekonomi Syariah (PKES). Perbankan Syariah. Jakarta: Pustak Komunikasi Ekonomi Syariah (pkes publishing), 2008.

Salim, Moh. Nur. Fikih Realistis: Kajian Tentang Hubungan antara Fikih dengan Realitas Sosial pada Masa Lalu dan Masa Kini, E-Book. 2009. 
Sjahdeini, Sutan Remi. Perbankan Syariah: Produk-produk dan Aspek-aspek Hukumnya. Jakarta: Kencana, 2014.

Soemitra, Andri. Bank dan Lembaga Keuangan Syariah. Jakarta: Kencana Prenada Media Group, 2012.

Susanto, Burhanuddin. Hukum Perbankan Syariah di Indonesia. Yogyakarta: UII Press, 2008.

Widodo, Hertanto et. al. PAS (Pedoman Akuntansi Syariah): Panduan Praktis Operasional Baitul Mal wat Tamwil (BMT). Bandung: Mizan, 2000.

Wirdyaningsih et al. Bank dan Asuransi Islam di Indonesia. Jakarta: Kencana, 2005.

Yaya, Rizal. Akuntansi Perbankan Syariah: Teori dan Praktik Kontemporer. Jakarta: Salemba Empat, 2012. 